\title{
Proses Pengawasan Dewan Kemakmuran Masjid dalam Peningkatan Kegiatan Santri
}

\author{
Muhammad Fajar Taufiq 1*, Dewi Sadiah $2^{1}$, Herman $2^{2}$ \\ 123Jurusan Manajemen Dakwah, Fakultas Dakwah dan Komunikasi, UIN Sunan Gunung Djati, \\ Bandung \\ *Email : m.fajar.tanfig@gmail.com
}

\begin{abstract}
ABSTRAK
Tujuan penelitian ini adalah untuk mengetahui dan menggambarkan proses pengawasan DKM Rahmatan Lil'alamin dalam perumusan standar pengawasan, hasil pengawasan, dan tindakan perbaikan DKM Rahmatan Lil'alamin terhadap penyimpangan yang ada dalam kegiatan santri untuk meningkatkan kegiatan santri. Metode penelitian yang digunakan yaitu metode deskriptif, dengan teknik pengumpulan data melalui wawancara, observasi langsung ke lapangan dan analisis dokumen sehingga diperoleh data yang valid. Hasil penelitian ini menunjukan bahwa proses pengawasan terhadap kegiatan santri telah diterapkan dengan baik dilihat dari penetapan standar-standar pengawasan yang terbukti dengan adanya Standar Oprasional Prosedur (SOP) yang dijadikan standar dalam proses pengawasan. Kemudian hasil pengawasan terhadap kegiatan santri dibuat laporan yang tersusun rapih dalam bentuk Laporan Pencapaian Sasaran (LPS) yang akan dibahas untuk bahan evaluasi ketika diselenggarakan rapat. Kemudian ada tindakan perbaikan yang dilakukan oleh DKM Rahmatan Lil'alamin yaitu tindakan perbaikan langsung dan tidak langsung. Tindakan perbaikan ini dilakukan untuk meningkatkan kegiatan agar lebih baik dan produktif.
\end{abstract}

Kata Kunci : Pengawasan, Masjid, Kegiatan, Santri.

\section{ABSTRACT}

The purpose of this research is to know and describe the DKM supervision process of Rabmatan lil'alamin in formulating the standards of supervision, supervision, and corrective action of DKM Rahmatan lil'alamin against the irregularities present in the activities Students to increase the students 'activities. The research method used is a descriptive method, with the technique of collecting data through interviews, direct observation to the field and analysis of documents so that the data obtained valid. The results of this study showed that the supervision of the students ' activities has been properly applied in the determination of the supervisory standards proven by 
the standards of the oprational procedures (SOP) as standard in monitoring process. Then the results of supervision on the activity is made a report that arranged neatly in the form of Target Achievement Report (LPS) that will be discussed for evaluation material when beld tightly. Then there is a corrective action performed by DKM Rahmatan Lil'alamin which is a direct and indirect corrective action. This corrective action is performed to improve activities to be better and productive.

Keywords : Controling, Mosque, Activities, Students.

\section{PENDAHULUAN}

Tujuan penulis melakukan penelitian tentang Proses Pengawasan Dewan Kemakmuran Masjid (DKM) ini yaitu untuk mengetahui bagaimana proses yang dilakukan dalam penerapan fungsi pengawasan di Masjid Rahmatan Lil'alamin, dimulai dari bagaimana penetapan standar pengawasan yang diterapkan, seperti apa hasil pengawasan yang dilakukan Dewan Kemakmuran Masjid Rahmatan Lil'alamin dalam kegiatan-kegiatan di masjid, dan juga seperti apa tindakan perbaikan yang dilakukan apabila terjadi sebuah penyimpangan dalam kegiatankegiatan yang ada.

Masjid merupakan sebuah unsur penting dalam kehidupan masyarakat islam, dimana masjid itu ialah tempat untuk beribadah, melakukan kegiatankegiatan keagamaan seperti pengajian Al-Qur'an, pengajian bapak-bapak atau ibuibu, dan juga tempat kehidupan umat muslimin dan lain-lainnya. Bahkan pada masa sekarang ini masjid-masjid sudah lebih terorganisir dari tataran Dewan Kemakmuran Masjid (DKM). Kepengurusan Dewan Kemakmuran Masjid mempunyai tanggung jawab untuk memakmurkan masjid dengan kegiatankegiatan keagamaan agar dakwah islam tetap berlangsung di dalamnya akan tetapi tidak hanya Kepengurusan Dewan Kemakmuran Masjid dan Organisasi yang ada di dalamnya saja yang mempunyai tanggung jawab memakmurkan masjid melainkan masyarakat sekitar atau jamaah masjid tersebutpun harus ikut andil dalam memakmurkan masjid.

Bila dilihat secara fisik banyak bangunan-bangunan masjid di setiap sudut daerah sudah baik, namun pemanfaatannya tidak cukup baik (Qadaruddin, 2016:225). Demi ingin meramaikan masjid secara serba terus dan giat, ia harus dikendalikan (Gazalba, 1989:369). Organisasilah yang bisa mengendalikan masjid baik dari segi kegiatan dakwah dan juga perkara sosialnya. Para remaja islamlah yang lebih cocok untuk ikut andil dalam kegiatan-kegiatan dakwah di masjid. Tentunya organisasi tersebut harus bisa menerapkan fungsi-fungsi manajemen dengan baik agar setiap kegiatan yang dilaksanakan dapat berjalan dengan baik pula.

Pengawasan merupakan fungsi terakhir dari proses manajemen (Hasibuan, 2007:241). Untuk mengoptimalkan pelaksanaan dari semua kegiatan santri yang 
ada di masjid Rahmatan Lil'alamin Eco Pesanten ketua DKM mengawasi mekanisme pelaksanaan kegiatan yang dilakuan santri Eco Pesantren. Pengawasan ini sangat terkait dengan perencanaan yang sudah dibuat, karena pengawasan atau pengendalian ini baru dapat dilakukan jika sudah ada rencana yang dibuat.

Kegiatan sehari-hari yang ada di Masjid Rahmatan Lil'alamin dilaksanakan oleh para santri dari Eco Pesanten DT. Santri adalah calon penerus para ulama yang perlu untuk dididik, dibina serta diberi pengawasan (Hidayatulloh, (2016:39) Oleh sebab itu kegiatan-kegiatan yang dilaksanakan di masjid Rahmatan Lil'alamin tidak terlepas dari pengawasan ketua Dewan Kemakmuran Masjid, agar semua kegiatan-kegiatan yang dilaksanakan berjalan dengan semestinya maka peran ketua DKM mengawasi terhadap para santri Eco Pesantren serta kegiatan-kegiatan yang dilaksanakannya di masjid Rahmatan Lil'alamin.

Ketua DKM harus melakukan pengawasan dengan cara pemerikasaan, pengecekan terhadap kegiatan yang dilaksanakan demi mencegah adanya kemungkinan penyimpangan atau penyelewengan. Dalam berorganisasi, pengawasan sangat penting demi keberlangsungan kegiatan yang sudah direncanakan. Jika tidak ada pengawasan yang baik organisasi akan sulit untuk mencapai segala tujuan kegiatan-kegiatan yang sudah direncanakan sebelumnya.

Dalam kepengurusan Dewan Kemakmuran masjid ini DKM membentuk sebuah organisasi Ikatan Remaja Masjid berdasarkan kebutuhan akan sumberdaya manusia untuk membantu mengelola kegiatan-kegian yang ada di masjid Rahmatan li'alamin dan juga untuk meningkatkan kegiatan santri dalam melaksanakan kegiatan-kegiatan yang telah ada di masjid Rahmatan Lil'alamin. Sehingga masjid tidak akan sepi dari kegiatan-kegiatan dakwah dalam menyiarkan agama islam.

Diantara banyaknya organisasi agar para remaja bisa ikut berperan aktif dan sebagai pembelajaran dakwah Islamiyah salah satunya ialah organisasi yang ada di masjid Rahmatan li'alamin Eco Pasantren yaitu Ikatan Remaja Masjid (IRMAS) yang merupakan sebuah organisasi santri Eco Pasantren sebagai media pembelajaran berorganisasi untuk mendapatkan sejumlah manfaat serta wawasan keislaman dan juga mempererat ukhwah Islamiyah diantara para remaja.

Organisasi Ikatan Remaja Masjid (IRMAS) ini berada dalam naungan Dewan Kemakmuran Masjid Rahmatan Lil'alamin yang senantiasa diberi pembinaan dan pengawasan oleh Dewan Kemakmuran Masjid (DKM) agar organisasi remaja masjid yang ada ini bisa menjadi kader penerus Dewan Kemakmuran Masjid (DKM) supaya kegiatan yang ada di masjid tidak sepi yang hanya untuk kegiatan peribadahan saja dan juga senantiasa menjadi penerus umat islam dalam berorganisasi dengan bekal yang sudah dipelajadi dari organisasi Ikatan Remaja Masjid Rahmatan lil'alamin. 
Penelitian Suryani (2000) mengenai fungsi pengawasan dalam pelaksanaan kegiatan pada organisasi ikatan remaja masjid bahwa pengawasan dalam pelaksanaan kegiatan dilakukan dengan cara pengawasan langsung dan tidak langsung. Dimana dengan cara pengawasan langsung dan tidak langsung dapat menummbuhkan disiplin kerja dan juga produktivitas yang tinggi bagi setiap pengurus IKRIMA At-Tawakal, hal ini merupakan suatu yang sangat positif bagi organisasi. Dengan demikian dapatlah disimpulkan bahwa pengawasan dari ketua sangat mempengaruhi kelancaran mekanisme pelaksanaan kegiatan pada organisasi Remaja Masjid At-Tawakal.

Penelitian Hariroh (2005) mengenai model pengawasan pimpinan Pondok Pesantren Al-Mardiah dalam upaya mewujudkan lembaga yang professional, bahwa model pengawasan yang digunakan oleh pimpinan Pondok Pesantren AlMardiyah Al-Islamiyah adalah model menurut waktu pelaksanaan. Dimana pimpinan mengunakan tiga dasar kontrol yaitu; sistem control tradisional, sistem kontrol feedback, dan sistem kontrol feedforward.

Penelitian Jeanudin (2007) mengenai proses pengawasan terhadap kaderisasi da’i di Yayasan An-Warul Huda, bahwa metode pengawasan langsung dipandang lebih efektif dibandingkan dengan pengawasan tidak langsung. Ini didasarkan pada pengawasan langsung lebih bertuju pada objek yang diawasi, sehingga lebih terukur dan mudah diawasi.

Penelitian ini dilakukan di Masjid Rahmatan Lil'alamin Eco Pesantren Daarut Tauhid yang beralamatkan di Jln. Cigugur Girang Parompong Kabupaten Bandung, Jawa Barat. Terpilihnya Masjid Rahmatan Lil'alamin sebagai lokasi penelitian dikarenakan di dalam kepemimpinan DKM Masjid Rahmatan Lil'alamin telah menerapkan prinsif-prinsif manajemen khususnya dalam masalah pengawasan yang sesuai dengan studi peneliti pada Jurusan Manajemen Dakwah. Sehingga dapat memudahkan peneliti dalam penyelesaian masalah.

Fokus penelitian ini difokuskan pada proses pengawasan DKM terhadap peningkatan kegiatan santri. Dari fokus penelitian tersebut dapat memberikan dasar pemikiran dalam permasalahan pokok diantaranya; Pertama, penetapan standard-standar pengawasan terhadap peningkatan kegiatan santri di Masjid Rahmatan Lil'alamin. Kedua, hasil pengawasan DKM terhadap peningkatan kegiatan santri di Masjid Rahmatan Lil'alamin. Ketiga, tindakan perbaikan yang dilakukan DKM jika terdapat penyimpangan dalam pelaksanaan kegiatan santri di Masjid Rahmatan Lil'alamin.

Pada penelitian ini, penulis menggunakan metode deskriptif dengan pendekatan kualitatif. Sugiono dalam buku Sadiah (2015:4) menyatakan bahwa deskriptif ialah suatu rumusan masalah yang memandu penelitian untuk mengeksplorasi atau memotret situasi sosial yang akan diteliti secara menyeluruh, luas dan mendalam. 
Berdasarkan pemaparan di atas, sangat penting sekali untuk diteliti lebih dalam mengenai proses pengawasan Dewan Kemakmuran Masjid terhadap peningkatan kegiatan santri. Untuk mengetahui seperti apa proses pengawasan yang dilakukan Dewan Kemakmuran Masjid Rahmatan Lil'alamin.

\section{LANDASAN TEORITIS}

Dalam proses pelaksanaan kegiatan yang ada di masjid, Dewan Kemakmuran Masjid (DKM) selalu mengawasi pada setiap kegiatan-kegiatan yang merupakan sebuah program kegiatan masjid tersebut. Agar kegiatan lebih terlaksana dengan sebaik mungkin, proses pengawasan dilakukan oleh DKM terhadap keberlangsungan kegiatan santri-santri Eco Pesantren yang ada di Masjid Rahmatan Lil'alamin yang mana kegiatan-kegiatan tersebut sangat memerlukan pengawasan sepaya kegiatan-kegiatan tidak melenceng dari apa yang sudah direncanakan dan sesuai dengan tujuannya.

Pengawasan merupakan tindakan atau proses kegiatan untuk mengetahui hasil pelaksanaan, kesalahan, dan kegagalan. Untuk demikian, dilakukan perbaikan atau mengulang kembali kesalahan-kesalahan itu, begitu pula menjaga agar pelaksanaan tidak berbeda dengan rencana yang ditetapkan (Julitriarsa, 1998:101).

Menurut Harold Koontz yang dikutip oleh Hasibuan (2011:241) mengemukakan bahwa pengawasan adalah "Control is the measurementand correction of the performance of subordinates in order to make sure that enterprise objecives and plans devised to attain then are accomplishied". Artinya pengendalian adalah pengukuran dan perbaikan terhadap pelaksanaan kerja bawahan, agar rencana-rencana yang telah dibuat untuk mencapai tujuan-tujuan perusahaan dapat terselenggara.

Adapun dalam proses pengawasan setidaknya ada empat langkah, hal tersebut dapat digambarkan dengan bagan sebagai berikut: 


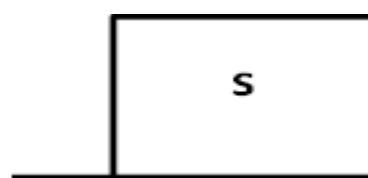

1) Penentuan Standar atau dasar pengawasan

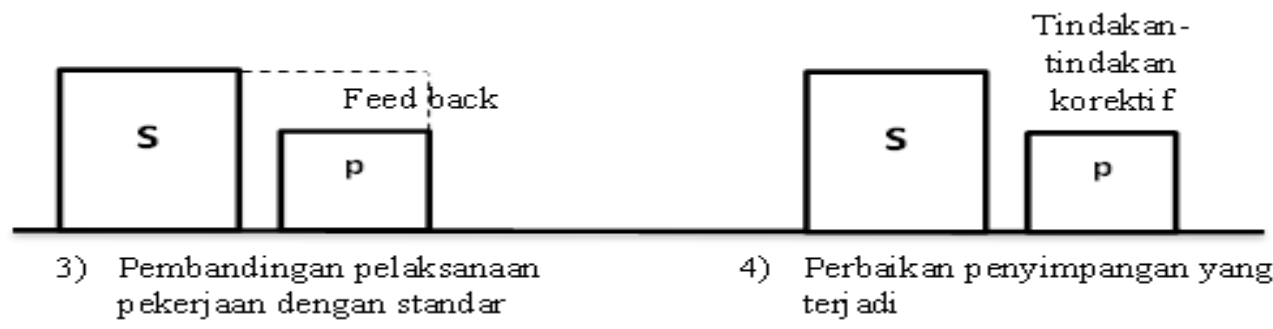

Sumber: Sarwoto (1981: 99).

\section{Gambar 1. Proses Pengawasan.}

Berdasarkan gambar 1 diatas, proses pengawasan memiliki beberapa langkah-langkah atau tindakan-tindakan tertentu yang bersifat fundamental bagi semua pengawasan managerial yang dilakukan secara bertahap.hal ini berdasarkan pendapat Terry yang dikutip dalam bukunya Sarwoto (1981: 99), yaitu meliputi: Pertama, Penentuan ukuran atau pedoman baku (standar). Kedua, Penilaian atau pengukuran terhadap pekerjaan yang sudah atau senyatanya dikerjakan. Ketiga, Perbandingan antara pelaksanaan pekerjaan dengan ukuran atau pedoman baku yang telah ditetapkan untuk mengetahui penyimpangan-penyimpangan yang terjadi. Keempat, Perbaikan atau pembetuan terhadap penyimpanganpenyimpangan yang terjadi, sehingga pekerjaan tadi sesuai dengan apa yang telah direncanakan.

Adapun diterapkannya pengawasan memiliki beberapa tujuan, diantaranya; Pertama, ketentuan-ketentuan yang direncanakan dapat sesuai pada pelaksanaannya. Kedua, apabila terjadi kesalahan atau penyimpanganpenyimpangan dapat dilakukannya tindakan perbaikain (corrective). Ketiga, supaya rencana bisa menghasilkan tujuan yang sesuai tujuan (Hasibuan, 2011:242).

Adapun menurut Hasibuan (2003:406) mengemukakan bahwasanya proses pengawasan terdiri dari beberapa hal, diantaranya:

Pertama, Menetapkan standar dan metode pengukuran. Sebelum melakukan tahapan yang lain, menetapkan standar dan metode pengukuran harus dilakukan terlebih dahulu. Sebisa mungkin diusahakan standar yang ditetapkan dapat di ukur dan juga dirumuskan menggunakan kata-kata yang jelas sehingga mudah dimengerti dengan baik. 
Kedua, Melakukan pengukuran prestasi. Setelah proses penetapan standar tahapan selanjutnya adalah melakukan pengukuran prestasi. Tahapan ini merupakan tahap yang perlu dilakukan beberapa kali atau berulang-ulang dengan meninjau pada situasi dan juga keadaan untuk mengukur prestasi atau hasil pengawasan sesuai dengan situasi dan kondisi.

Ketiga, Membandingkan apakah prestasi yang dicapai sesuai dengan standarnya. Apabila pencapaian prestasi dapat melebihi dari standar yang telah ditentukan, sudah pasti pelaksanaan kegiatannya berjalan amat baik, dalam hal ini barangkali tidak diperlukannya tindakan perbaikan. Apabila tindakan perbaikan diperlukanpun, untuk meningkatkan kualitas agar bias lebih baik lagi.

Keempat, Melakukan perbaikan-perbaikan yang diperlukan. Dengan dilakukannya tindakan perbaikan, perubahan standar atau cara bekerja sekaligus segala aktivitas yang ada bisa terlibat dalam tindakan perbaikan ini karena tindakan perbaikan dapat mengubah sesuai dengan apa yang diperlukan.

Keberadaan masjid dalam konteks sosiologis yang demikian penuh warna tentu buakan hanya sekedar pelengkap ritual formal. Menurut Nugraha (2016:4) masjid merupakan community center, pusat penanggulangan krisis yang dihadapi masyarakat sekitarnya. Umat Islam seharusnya bisa mempersiapkan masa depan dalam seluruh aspek kehidupan, baik itu dari segi agama, ekonomi, politik, sosial, dan sebagainya. Seperti yang ada dalam sejarah bahwa masjid merupakan tempat yang diperuntukan dalam segala aspek sendi-sendi seluruh kehidupat terpusan di masjid.

Menurut pendapat Harahap (1996:10) mengemukakan bahwa fungsi masjid itu bukan sekedar untuk tempat peribadahan saja, akan tetapi masjid bisa berfungsi untuk menjadi tempat madrasah untuk belajar agama maupun umum, tempat musyawarah bersama, tempat kegiatan warga setempat, pernikahan, dan bahkan kegiatan olahraga, kesenian dan yang lainnya bisa dilakukan di masjid. Perkembangan seperti ini sudah cukup banyak diterapkan pada masjid-masjid di setiap daerah.

Kemudian Nugraha (2016:61) mengemukakan tentang pengorganisasian masjid, bahwa: pertama, sistem pengorganisasian masjid adalah salah satu fungsi serta sistem manajemen yang didalamnya mempunyai sub-sub sistem tersendiri yang saling berkaitan dalam pengelolaan masjid. Kedua, sistem pengorganisasian masjid adalah rangkaian sistem yang terdiri dari sumber daya manusia, sumber daya lain (non manusia atau materi dan immaterial) yakni sebagai perangkat penunjang organisasi, proses kerja, dan tujuan atau sasaran kerja. Ketiga, sistem pengorganisasian masjid dalam proses aktivitasnya terdiri dari rangkaian kerja untuk menentukan dan menyusun desain kerja, mengelompokan kerja menjadi satuan tugas kerja, pendelegasian wewenang kepada individu dan strukturisasi. 
Keempat, sistem pengorganisasian masjid tidak bisa terlepas dan bersiri sendiri tanpa adanya pengaruh dari luar sistemnya yakni sistem sebagai fungsi dipandang adanya saling ketergantungan dan keterikatan dengan fungsi-fungsi lainnya.

Kegiatan yang dilakukan oleh seorang siswa/santri tidak luput dari kegiatan kegamaan, terutama kegiatan yang dilaksanakan oleh santri di masjid ialah sebuah kegiatan keagamaan. Untuk mendekatkan diri kepada Allah SWT dengan meningkatkan ketaqwaan serta keimanan, kegiatan keagamaan ini sangat penting dilakukan agar senantiasa membiasakan diri dengan kkegiatan-kegiatan agama, selain itu juga dengan melakukan kegiatan keagamaan kita dapat bersosial dengan masyarakat sekitar dalam kebersamaan umat islam.

Kegiatan keagamaan dapat diartikan segala aktifitas agama islam untuk menyiapkan peserta didik melalui kegiatan bimbingan, pengajaran, atau latihan bagi peranannya di masa yang akan datang. Keagamaan adalah sifat-sifat yang terdapat dalam agama atau segala sesuatu mengenai agama (Poerwodarminto, 1997:26). Jadi, kegiatan keagamaan ialah segala bentuk perbuatan seseorang yang berkaitan dengan agama.

Adapun kata santri menurut Majid (1997:20) adalah murid seorang kyai dalam ruang lingkup pesantren, murid tersebut bisa disebut santri apabila ia bisa memperoleh kerelaan sang kyai dan juga mengikuti segenap kehendak kyai dan melayani segenap kepentingan kyai. Hal tersebut adalah mutlak sebagai persyaratan menjadi seorang murid dari kyai dalam arti sepenuhnya. Kemudian dalam Yasmadi (2005:61) Nurcholis Majid juga berpendapat dalam pandangannya asal usul kata "santri" dapat dilihat dari dua pendapat. Pertama, pendapat yang mengatakan bahwa santri berasal dari kata "sastri", sebuah kata dai Bahasa sangseketa yang artinya melek huruf. Pendapat ini menurut Nurcholis Majid berdasarkan atas kaum santri kelas literary bagi orang jawa yang berusaha mendalami agama melelui kitab-kitab bertulisan dan berbahasa Arab. Kedua, pendapat yang mengatakan bahwa perkataan santri sesungguhnya berasal dari Bahasa jawa, dari kata "cantrik" berarti seorang yang selalu megikuti seorang guru kemana guru ini pergi menetap.

\section{HASIL DAN PEMBAHASAN}

Masjid Rahmatan Lil'alamin merupakan masjid yang berdiri dalam lingkungan pesantren dimana mayoritas jama'ah masjid tersebut adalah para santri-santri dari Eco Pesantren yang aktif dalam kegiatan-kegiatan di Masjid Rahmatan Lil'alamin baik itu kegiatan keagamaan, kegiatan social dan lain-lain. Masjid rahmatan Lil'alamin beralamat di Jln. Cigugur Girang, Kecamatan Parompong, Kabupaten Bandung, Jawa Barat.

Dalam berdirinya Masjid Rahmatan Lil'alain diawali pada tahun 2005 Masehi karena mendapat usul dari AA Gym untuk membangun masjid. 
Pembangunan Masjid Rahmatan Lil'alamin menggunakan konsep bangunan yang memiliki resapan air dan juga ruang terbuka hijau. Pembangunan Masjid Rahmatan Lil'alamin bertahap setiap tahunnya seperti konsep pembangunan "rumah tumbuh", hingga saat ini Masjid Rahmatan Lil'alamin memiliki bangunan yang cukup luas untuk menjalankan kegiatan-kegiatan dakwah sehari-harinya.

Diantara banyaknya masjid-masjid yang telah menerapkan manajerial yang baik, Masjid Rahmatan Lil'alamin adalah salah satu masjid yang menerapkan manajerial dengan cukup baik dari segi perencanaan, pengorganisasian, pengawasan, dan pelaksanaannya. Dalam hal pengawasan, ketua Dewan Kemakmuran Masjid Rahmatan Lil'alamin berkordinasi dengan staf-staf DKM dan juga Ikatan Remaja Masid Rahmatan Lil'alamin yang beranggotakan santrisantri di Eco Pesantren.

Masjid Rahmatan Lil'alamin memiliki banyak program kegiatan yang dijalankan oleh Dewan Kemakmuran Masjid Rahmatan Lil'alamin, adapun program kegiiatan yang ada di Masjid Rahmatan Lil'alamin terbagi menjadi empat program berdasarkan waktu kegiatan tersebut, yaitu program harian, mingguan, bulanan dan tahunan.

Pertama, Kegiatan harian yang ada di Masjid Rahmatan Lil'alamin berupa; Bersih, Rapi, Tertib, dan Teratur (BRTT) bagian dalam dan luar masjid, pengecekan lampu masjid, pengecekan sound, pengumuman waktu adzan, tilawah sebelum adzan, shalat fardhu, pembacaan hadits, dzikir alma'tsurat, mendengarkan kajian shubuh pgi, pembuatan JOBDESK IRMAS, kontrol jadwal khidmat, dan kontrol penggunaan masjid.

Kedua, Kegiatan mingguan yang ada di Masjid Rahmatan Lil'alamin berupa; pengajian majlis taklim ibu-ibu, shalat jum'at, kajian hikamm dan ma'rifatullah, koordinasi dengan imam dan Ikatan Remaja Masjid Rahmatan Lil'alamin, dan kajian ibu-ibu.

Ketiga, Kegiatan bulanan yang ada di Masjid Rahmatan Lil'alamin berupa; pembelian peralatan kebersihan, kajian tauhiid (sebulan sekali), pengajian ibu-ibu DTA, pelaksanaaan MABIT dan TASMI', menerbitkan berbagai administrasi DKM, Laporan Pencapaian Sasaran DKM, dan kajian muslimat.

Keempat, Kegiatan tahunan yang ada di Masjid Rahmatan Lil'alamin berupa; Paket Ramadhan, penyebaran Daging Qurban, wakaf peralatan Masjid Rahmatan Lil'alamin, BANSOS untuk DTA se-Cigugur, pengajuan ruang kelas khusus DTA dan KOBER, infaq untuk guru ngaji, pengajuan beasiswa untuk anak-anak warga, PHBI (Peringatan Hari Besar Islam), kerjasama pelatihan, SANLAT Ramadhan, I'tikaf, Idul Fitri, Idul Adha, Takjil Ramadhan, dan SANLAT Ramadhan.

\section{Penetapan Standar-Standar Pengawasan DKM Rahmatan Lil'alamin}


Standar-standar pengawasan ini dirumuskan oleh para staf Dewan Kemakmuran Masjid beserta para jajaran staf yang ada di kantor Wakaf Eco Pesantren ikut serta andil dalam merumuskan standar-standar pengawasan yang dapat disebut juga sebagai standar prestasi.

Perumusan standar pengawasan ini dilakukan pada saat RaKer (Rapat Kerja) Tahunan yang biasanya diadakan pada tiga bulan sebelum pergantian tahun. Dalam menentukan standar pengawasan ini Dewan Kemakmuran Masjid meninjau dari hasil evaluasi yang terdahulu, lalu Dewan Kemakmuran Masjid membuat beberapa SOP (Standar Operasional Prosedur) untuk mengawasi kegiatan-kegiatan demi meningkatkan kualitas kegiatan santri. Perumusan standar di sini harus ditinjau dengan sangat matang, supaya standar tersebut bisa menjadikan peningkatan kegiatan-kegiatan yang ada di Masjid Rahmatan Lil'alamin.

Dengan adanya penetapan strandar, pengawasan akan tersusun dengan rapih sesuai dengan asas pengawasan yang dikemukakan oleh Hasibuan (2011:243) bahwasanya pengawasan harus bisa tersusun dengan baik agar mencerminkan pengawasan tersusun dengan rencana. Penetapan standar pengawasan akan berdampak pada kinerja para santri. Karena dengan adanya penetapan standar pengawasan ini santri-santri akan melaksanakan kegiatan sesuai dengan arahan yang ada. Pengawasan yang dilakukan Dewan Kemakmuran Masjid Rahmatan Lil'alamin membuat santri akan merasa lebih diperhatikan dalam melaksanakan kegiatan-kegiatan yang ada di Masjid Rahmatan Lil'alamin. hal ini menjadikan nilai produktivitas santri bertambah, sehingga kualitas kegiatan yang dilaksanakan oleh santri tersebut bisa lebih baik.

Menurut Yunus (2013:122) pengawasan adalah proses performa organisasi atau perusahaan untuk memastikan bahwa jalannya organisasi sesuai dengan rencana. Hal ini menjadika standar pengawasan itu perlu untuk diterapkan dalam organsasi agar keberlangsungan kegiatan-kegiatan yang ada dapat sesuai dengan yang direncanakan.

Ketua DKM Ramatan Lil'alamin Ustad Pepep Hambali beserta staf jajaran DKM Rahmatan Lil'alamin dan juga Ikatan Remaja Masjid harus senantiasa bisa mengikuti prosedur atau standar yang sudah ditetapkan pada setiap kegiatan yang ada dan juga DKM Rahmatan Lil'alamin harus bida berorganisasi dengan staf jajaran beserta IRMAS Rahmatan Lil'alamin, karena proses pendelegasian wewenang beresta tanggung jawab yang baik dapat didapatkan dari sebuah proses pengorganisasian yang teratur secara menyeluruh (Alkhairy, 2017:64). Sehingga dalam proses pengawasanya juga bisa lebih mudah dan lebih terstruktur dengan rapih.

Adapun diantaranya contoh standar-standar yang telah dirumuskan diantaranya ialah standar aktivitas shalat lima waktu yang sudah ditepatkan 
standar-standarnya. Oleh karna itu Dewan Kemakmuran Masjid Rahmatan Lil'alamin membuat standar yang harus terstruktur agar berjalan dengan baik.

Tujuan dari standar yang ditetapkan ini supaya memberikan pelayanan yang terbaik kepada jamaah yang melaksanakan ibadah shalat lima waktu di Masjid Rahmatan Lil'alamin. Secara lebih luasnya ialah; (1) Memberikan pelayanan yang terbaik kepada jamaah yang melaksanakan ibadah shalat lima waktu Masjid Rahmatan Lil'alamin. (2) Memberikan Service Excellent. (3) Menjadikan Masjid Rahmatan Lil'alamin sebagai salah satu contoh dari proses manajemen masjid oleh orang lain.

Beberapa indikator yang menentukan keberhasilan dari kegiatan shalat wajib lima waktu, yaitu; (1) Waktu pelaksanaan ibadah sesuai dengan jadwal yang ditetapkan pemerintah (mengacu kepada jadwal Kemenag kota Bandung Barat). (2) Petugas Imam dan Muadzin terstandar (adanya rekomendasi dari Laznah dan DKM). (3) Suara muadzin dan imam terdengar jelas oleh jamaah yang meliputi semua area shalat. (4) Jamaah aman, nyaman dan tertib dalam melaksanakan ibadah Shalat Lima Waktu. (5) Terpenuhinya sarana dan prasarana yang menunjang aktivitas ibadah Shalat lima Waktu.

Kemudian untuk kebijakan yang ditetapkan oleh Dewan Kemakmuran Masjid dalam pelaksanaan kegiatan shalat wajib lima waktu, yaitu: (1) Masjid senantiasa memberikan pelayanan ibadah shalat wajib lima waktu berjamaah. (2) Adzan dikumandangkan tepat waktu sesuai dengan jadwal yang dikeluarkan oleh lembaga resmi ( Kementerian Agama RI ). (3) Sarana ibadah berupa tikar dan soundsystem, Video, harus tersedia di setiap lokasi diselenggarakannya shalat berjamaah sehingga suara imam dapat didengar oleh seluruh jamaah shalat berjamaah. (4) Air untuk thaharah harus senantiasa tersedia selama 24 jam per hari. (5) Tempat beribadah harus dalam keadaan bersih dan suci dari najis, kotoran, dan sampah. (6) Masjid senantiasa dalam keadaan BRT'T (Bersih, Rapih, Tertib, dan Teratur). (7) Petugas yang harus tersedia ialah Imam beserta badalnya, Muadzin, Operator Sound System, Petugas Pengatur Shaff, Cleaning Service, Petugas Perapihan Alas Kaki, dan Keamanan.

Kemudian kriteria proses kegiatan shalat lima waktu yang telah ditetapkan oleh DKM Rahmatan Lil'alamin ialah Sebagai Berikut:

Table 1. kriteria proses kegiatan.

Persiapan Shalat Wajib Masjid siap digunakan untuk kegiatan shalat lima waktu. Lima Waktu 


\begin{tabular}{|c|c|}
\hline $\begin{array}{l}\text { Penyediaan Sarana } \\
\text { Bersuci }\end{array}$ & $\begin{array}{l}\text { Air harus terisi penuh satu jam sebelum pelaksanaan shalat lima } \\
\text { waktu. }\end{array}$ \\
\hline [Bagian Sarana] & $\begin{array}{l}\text { Sarana pendukung untuk berwudhu; 1) Keran air dalam keadaan } \\
\text { bisa digunakan. 2) saluran air pembuangan lancar. 3) Lantai bersih. } \\
\text { 4) Ruangan wudhu wangi. }\end{array}$ \\
\hline \multirow{4}{*}{$\begin{array}{l}\text { Penyediaan Sarana } \\
\text { Ibadah Shalat } \\
\text { [Bagian Sarana] }\end{array}$} & Tersedia jam penunjuk waktu shalat dan iqomah. \\
\hline & Tersedia lampu pencahayaan yang cukup. \\
\hline & Tersedia sajadah khusus untuk imam. \\
\hline & $\begin{array}{l}\text { Seluruh sarana tersedia dalam keadaan siap digunakan paling lambat } \\
15 \text { menit sebelum Adzan. }\end{array}$ \\
\hline \multirow{2}{*}{$\begin{array}{l}\text { Penyiapan Sound } \\
\text { System dan Alat Bantu } \\
\text { Visual }\end{array}$} & Suara adzan terdengar jelas \\
\hline & Suara imam terdengar jelas. \\
\hline \multirow[t]{2}{*}{$\begin{array}{l}\text { [Operator Sound } \\
\text { System] }\end{array}$} & $\begin{array}{l}\text { Seluruh sarana siap digunakan paling lambat } 15 \text { menit sebelum } \\
\text { adzan. }\end{array}$ \\
\hline & Ada operator sound system yang standby. \\
\hline \multirow{3}{*}{$\begin{array}{l}\text { Pelaksanaan Shalat } \\
\text { Berjamaah } \\
\text { [Kabag Ibadah] }\end{array}$} & Adzan tepat waktu. \\
\hline & $\begin{array}{l}\text { Waktu Iqomah Standar sbb; Subuh : } 10 \text { menit, Dhuhur : } 10 \text { menit, } \\
\text { Ashar : } 8 \text { menit, Maghrib : } 8 \text { menit/ } 10 \text { menit (Senin dan Kamis, } \\
\text { Ramadan), Isya : } 8 \text { menit }\end{array}$ \\
\hline & $\begin{array}{l}\text { Standar Pakaian Imam dan Muadzin; Berpakaian rapih (tidak kaos), } \\
\text { Memakai peci / sorban dan Memakai minyak wangi. }\end{array}$ \\
\hline \multirow{2}{*}{$\begin{array}{l}\text { Perapihan Sarana } \\
\text { (Tikar, Sound, TV) }\end{array}$} & Sarana yang telah digunakan dikembalikan ke tempat semula. \\
\hline & TV, Sound System, Lampu, dalam keadaan mati. \\
\hline
\end{tabular}

Sumber: DKM Rahmatan Lil'alamin 2019.

Berdasarkan table 1 diatas menjelaskan bahwa proses pelaksanaan kegiatan Shalat lima watu telah ditetapkan secara menyeluruh, mulai dari persiapan sebelum shalat dilaksanakan sampai perapihan sarana-sarana yang digunakan. Kriteria proses diatas juga menjelaskan standar yang harus terpenuhi dalam sebuah kegiatan shalat lima waktu seperti halnya penyediaan sarana bersuci dimana bak penampung air harus terisi penuh sebelum waktu shalat.

Standar seperti di atas pulu merupakan bagian dari jenis pengawasan time control (pengawasan waktu), pengawasan yang ditunjukan pada penggunaan waktu untuk mengerjakan sebuah kegiatan agar sesuai dengan rencana (Hasibuan, 2011:244).

Dari hasil penelitian mengenai penetapan standar pengawasan yang 
dilakukan oleh Dewan Kemakmuran Masjid Rahmatan Lil'alamin ini sudah cukup baik dengan adanya tujuan, kebijakan-kebijakan, indikator keberhasilan, dan juga kriteria proses pelaksanaannya sudah tersusun dan ditetapkan secara teratur dalam bentuk Standar Oprasional Proseder (SOP). Sehingga dengan adanya SOP ini bisa menjadi penunjang keberhaasilan kegiatan-kegiatan yang akan dilaksanakan oleh DKM Rahmatan Lil'alamin.

\section{Hasil Pengawasan Kegiatan Santri di Masjid Rahmatan Lil'alamin}

Dalam hal hasil pengawasan kegiatan santri yang berada di Masjid rahmatan Lil'alamin, Dewan Kemakmuran Masjid Rahmatan Lil'alamin memiliki pelaporan hasil kegiatan santri. Adapun waktunya dilakukan pada setiap minggu sekali, ada yang dilakukan pada setiap bulan sekali dan juga ada yang dilakukan pada setahun sekali.

Adapun kegiatan-kegiatan di masjid haruslah cukup padat demi mencapai suatu masjid berfungsi dengan baik (Harahap, 1996:49). Oleh karena itu, pengawasan yang dilakukan harus disesuaikan dengan kegiatan-kegiatan yang ada di Masjid Rahmatan Lil'alamin.

Hasil pengawasan menunjukan seperti apa pelaksanaan kegiatan dengan standar yg sudah ditetapkan apakah sesuai dengan yang direncanakan atau tidak.pengawasan ini ditujukan untuk mengetahui kualitas dan juga kuantitas produksi yang dihasilkan (Hasibuan, 2011:244).

Berdasarkan wawancara penulis dengan Ustad Pepep Hambali mengenai hasil pengawasan kegiatan, bahwa beliau mengatakan (Wawancara, 14 Oktober 2019).

Dari program yang kami jalankan, ada LPS (Laporan Pencapaian Sasaran) disana. Misalkan pada sebuah kegiatan masjid yang sudah ditetapkan standar prestasinya kemudian kegiatan itu kami laksanakan dengan sebagaimana mestinya lalu masing-masing penanggung jawab pada kegiatan tersebut memberikan laporan secara tertulis tentang bagaimana kegiatan itu terlaksana yang dituangkan pada LPS. Penyusunan Laporan Pencapaian Sasaran ini dilihat dari standar yang sudah kami buat, standar tersebut menjadi patokan untuk kami dalam melaksanakan pengawasan dalam pelaksanaan-pelaksanaan kegiatan dalam upaya peningkatan kegiatankegiatasn santri yang ada di Masjid Rahmatan Lil'alamin.

Dari wawancara tersebut dapat disimpulkan bahwa hasil pengawasan kegiatan Masjid Rahmatan Lil'alamin menitik beratkan pada LPS (Laporan Pencapaian Sasaran). Dari Laporan Pencapaian Sasaran menjadi bahan untuk evaluasi berhasil atau tidaknya sebuah kegiatan dan dari LPS pula pengawasan DKM Rahmatan Lil'alamin dapat meningkatkan kualitas kegiatan-kegiatan santri 
di Masjid Rahmatan Lil'alamin.

Hasil pengawasan merupakan sebuah pendeskripsian dari pelaksanaan proses pengawasan. Jika tidak adanya hasil pengawasan maka pengawasan itu tidak terlaksana atau pengawasan itu mengalami hambatan. Pada pelaksanaan pengawasan kegiatan-kegiatan santri, Dewan Kemakmuran Masjid berkoordinasi dengan Ikatan Remaja Masjid Rahmatan Lil'alamin karena merekalah yang lebih banyak turun ke lapangan pada setiap kegiatannya. Lalu Dewan Kemakmuran Masjid selaku pengawas, mengamati keberlangsunganya kegiatan dengan ikut terjun langsung ke lapangan atau mengawasi dengan melihat kegiatan yang dilakukan dari CCTV yang ada di Masjid Rahmatan Lil'alamin. kemudian untuk hasil pengawasan bisa bersisifat laporan lisan dan tulisan.

Laporan lisan biasanya laporan yang disampaikan secara langsung pada saat pelaksanaan kegiatan, laporan lisan seperti ini biasanya terjadi apabila adanya kesalahan atau penyelewengan dalam kegiatan. Sedangkan laporan tulisan disapaikan pada saat kegiatan telah terlaksana dan laporan tulisan ini menjadi bahan untuk didikusikan pada saat evaluasi. Pengawasan yang kami tetapkan dalam setiap kegiatan-kegiatan santri yang ada di Masjid Rahmatan Lil'alamin ini sangat memerlukan koordinasi yang baik antara pengawas dan juga santri. Kemudian hasil dari kegiatan-kegiatan yang telah diselenggarakan akan dicantumkan pada laporan pencapaian sasaran, yang nantinya diserahkan kepada Ketua Dewan Kemakmuran Masjid yaitu Ustad Pepep Hambali, penyerahan laporan tersebut diserahkan dan juga dibahas ketika ada rapat dengan ketua DKM Rahmatan Lil'alamin.

Hasil pengawasan kegiatan santri di Masjid Rahmatan Lil'alamin adalah hasil metode-metode pengawasan seperti pengamatan, laporan lisan atau tulisan, dan evaluasi. Hal tersebut berkesinambungan dengan teori metode pengawasan non-kualitatif, dimana pengawasan tidak melibatkan angka-angka dan dapat digunakan untuk mengawasi presentasi organisasi secara keseluruhan. Adapun teknik-teknik yang digunakan adalah; Pertama, Pengamatan (pengendalian dengan observasi).Kedua. Inspeksi teratur dan langsung. Ketiga, Laporan lisan dan tertulis. Keempat, Evaluasi. Kelima, Diskusi antara manajer dengan bawahan (Hanafi, 2003:412).

ketika dilakukannya pengawasan terhadap kegiatan yang berlangsung Dewan Kemakmuran Masjid berkordinasi dengan Ikatan Remaja Masjid melakukan inspeksi secara teratur yang bisa memberikan hasil kegiatan sesuai dengan apa yang sudah direncanakan. Dalam proses pengawasan pada kegiatan santri di masjid terkadang masih ada beberapa santri yang kurang kondusif seperti pada saat shalat berjama'ah ada santri yang telat atau bercanda, begitu juga pada kegiatan yang lainnya.

Dalam hasil pengawasan kegiatan santri yang ada di Masjid Rahmatan 
Lil'alamin itu akan berarti, jika disertai dengan proses pengawasan yang dilakukan. Adapun dalam proses pengawasannya Dewan Kemakmuran Masjid berkoordinasi dengan Ikatan Remaja Masjid Rahmatan Lil'alamin yang sangat berperan penting pada setiap kegiatan-kegiatan yang diaksanakan.

Kemudian hasil pengawasan tertulis akan diserahkan atau didiskusikan Bersama pada saat rapat yang telah diagendakan untuk membahas apakah kegiatan yang sudah terlaksana itu berjalan dengan semestinya seperti apa yang direncanakan, kemudian jika ada hal yang bersifat menyimpang dari rencana akan dicari solusi pada tahap evaluasi untuk menjadikan kegiatan-kegiatan yang ada bisa lebih baik lagi.

\section{Tindakan Perbaikan DKM Rahmatan Lil'alamin Terhadap Penyimpangan}

Dewan Kemakmuran Masjid Rahmatan Lil'alamin melakukan tindakan perbaikan sesuai dengan apa yang harus diperbaiki, apabila suatu kegiatan tidak ada penyimpangan-penyimpangan maka tindakan DKM Rahmatan Lil'alamin ialah mempertahankan konsistensi untuk menjaga sebuah proses keberlangsungan kegiatan itu tetap berjalan dengan baik dan tentunya dengan pengawasan yang tidak luput dalam proses pelaksanaan kegiatan-kegiatan.

Tahap pengawasan ini berkaitan dengan segala sesuatu yang melibatkan kegiatan karyawan (Hasibuan, 2011:244). Pada dasarnya segala bentuk kegiatan yang dilakukan di Masjid Rahmatan Lil'alamin oleh santri Eco Pesantren itu selalu diperhatikan baik secara langsung maupun tidak lanngsung seperti mengawasi melalui CCTV masjid.

Tahap ini ialah tahap terakhir dari proses pengawasan, tahap ini jugaa bias disebut dengan tahap evaluasi. Dari hasil pengawasn yang sebelumnya akan ditindak lanjuti apabila terjadi sebuah penyimpangan. Sehingga dapat memperbaki kinerja di masa kepengurusan selanjutnya (Huda, 2018:59).

Jika terjadinya penyimpangan-penyimpangan atau hal yang keluar dari prosedur oprasional kegiatan yang sudah ditetapkan oleh Dewan Kemakmuran Masjid, maka ada beberapa tindakan yang dilakukan Dewan Kemakmuran Masjid sesuai dengan penyelewangan seperti apa yang dilakukan tersebut. Dari situ pihak DKM Rahmatan Lil'alamin meninjau kembali seperti apa tindakan yang harus dilakukan, apakan tindakan secara langsung atau tidak langsung. Tindakan langsung apabila terjadi penyelewengan terhadap kegiatan santri seperti ada santri yang telat shalat berjamaah, bercanda pada saat kegiatan berlangsung dll, DKM Rahmatan Lil'alamin tidak melakukan tindakan penghukuman akan tetapi melakukan tindakan peneguran secara halus, mengarahkan santri kepada tindakan yang benar, dan juga memberikan contoh yang semetinya. Tindakan secara langsung ini bisa memberikan arahan tersendiri kepada santri agar bisa melakukan 
kegiatan dengan baik tanpa adanya hukuman yang mengandung unsur tindakan fisik yang biasanya lazim digunakan pada lembag-lembaga lain. Kemudian untuk tindakan perbaikan yang tidak langsung DKM Rahmatan Lil'alamin melakukan rapat yang sudah dijadwalkan, seperti rapat mingguan, bulanan, dan juga tahunan yang membahas evaluasi kegiatan-kegiatan yang sudah terlaksana.

Tindakan perbaikan langsung yang dilakukan DKM Rahmatan Lil'alamin apabila ada penyelewengan ialah tindakan yang berupa pengarahan, teguran, dan juga mencontohkan. Pengarahan yang dilakukan bersifat terbuka sehingga santri tidak merasa terintimidasi karena melakuan kesalahan, kemudian juga memberikan contoh yang baik dan dilakukan bersama-sama dengan IRMAS (Ikatan Remaja Masjid). Seperti yang dikatakan oleh Ustad Pepep Hambali (wawancara, 30 Agustus 2019), "Pada proses pengawasan kegitan Masjid Rahmatan Lil'alamin sangat terbantu dengan adanya IRMAS yang ikut serta andil membatu proses berjalannya kegiatan-kegiatan di Masjid Rahmatan Lil'alamin. Karena dalam hal proses pengawasan sangat penting sekali melakukan koordinasi dengan baik...".

Kemudian untuk tindakan perbaikan tidak langsung yang dilakukan Dewan Kemakmuran Masjid ada beberapa hal yang dilakukan, seperti rapat mingguan, bulan, dan tahunan. Pada rapat mingguan Dewan Kemakmuran Masjid Rahmatan Lil'alamin mengadakan rapat bersama anggota inti IRMAS yang diadakan pada setiah malam jum'at setelah harian selesai, pada rapat tersebut membahas tentang evaluasi kegiatan-kegiatan yang sudah terlaksana dan juga pelaporan hasil kegiatan sesuai dengan Penanggung Jawab masing-masing kegiatan. Pada rapat bulanan Dewan Kemakmuran Masjid.

Pada rapat bulanan yang diadakan DKM Rahmatan Lil'alamin, rapat tersebut merupakan rapat yang dilakukan dengan seluruh anggota IRMAS yang membahas tentang LPS sesuai dengan bidangnya masing-masing. Setelah meninjau dari rapat tersebut yang mengenai pelaksanaan kegiatan-kegiatan, Dewan Kemakmuran Masjid meninjau dari hasil yang dilaporkan oleh IRMAS kemudian menentukan secara bersama tindakan perbaikan apa yang dilakukan, demi meningkatkan kualitas kegiatan santri yang ada di Masjid Rahmatan Lil'alamin.

Kemudian rapat tahunan yang diadakan merupakan rapat yang beranggotakan seluruh staf Dewan Kemakmuran Masjid berserta staf kantor Wakaf Eco Pesantren yang membahas tentang evaluasi tahunan yang menjadi acuan untuk memperbaiki kegiatan yang akan dilakukan untuk tahun berikutnya.

Tindakan perbaikan yang dilakukan DKM Rahmatan Lil'alamin baik secara langsung maupun tidak langsung merupakan salah satu contoh tindakan penggerak dakwah juga. Menurut Mustofa (2017:3) adanya manajemen organisasi DKM sangatlah penting sebagai salah satu sarana dakwah, sebagai mana 
memungsikan masjid dengan sebagaimana mestinya.

Dengan demikian, tahapan proses pengawasan yang di terapkan oleh Dewan Kemakmuran Masjid Rahmatan Lil'alamin sesuai dengan teori proses pengawasan. Proses pengawasan DKM Rahmatan Lil'alamin telah terealisasikan dengan baik di Masjid Rahmatan Lil'alamin.

Tujuan dari adanya proses pengawasan adalah untuk meningkatkan kualitas kegiatan santri agar sesuai dengan apa yang sudah direncanakan berdasarkan proses pengawasan yang diterapkan. Kemudian agar pelaksanaan yang akan mendatang bisa lebih baik dari masa lalu maupun sekarang.

Demikian gambaran hasil penelitian yang telah dilakukan oleh penulis tentang "Proses Pengawasan Dewan Kemakmuran Masjid dalam Peningkatan Kegiatan Santri”. Metode yang dipilih oleh penulis yaitu metode deskriftif sudah tepat karena penulis bisa menggambarkan keadaan objektif penelitian secara luas berdasar fakta-fakta yang ada.

\section{PENUTUP}

Penetapan standar-standar pengawasan Dewan Kemakmuran Masjid Rahmatan Lil'alamin sudah dijalankan dengan baik yaitu terbukti dengan adanya Standar Oprasional Prosedur (SOP) yang sudah ditetapkan dan dirumuskan dengan baik, sehingga dapat diterapkan oleh Dewan Kemakmuran Masjid Rahmatan Lil'alamin dan membantu dalam keberlangsungan proses pengawasan kegiatan di Masjid Rahmatan Lil'alamin. Hasil pengawasan kegiatan santri di Masjid Rahmatan Lil'alamin yaitu pelaporan yang dibuat oleh masing-masing penanggung jawab kegiatan yang tersusun rapih dalam LPS (Laporan Pencapaian Sasaran). Tindakan perbaikan Dewan Kemakmuran Masjid Rahmatan Lil'alamin tehadap penyimpangan atau penyelewengan dalam pelaksanaan kegiatan berupa tindakan perbaikan secara langsung dan tidak langsung untuk berlangsungnya kegiatan yang lebih baik lagi.

Berdasarkan hasil penelitian, pembahasan dan kesimpulan mengenai Proses Pengawasan Dewan Kemakmuran Masjid dalam Peningkatan Kegiatan Santri di Masjid Rahmatan Lil'alamin Eco Pesantren. Maka peneliti akan memberikan beberapa saran untuk dijadikan pertimbangan untuk perbaikan dan meningkatkan proses pengawasan sehingga ke depannya dapat berjalan lebih optimal dan maksimal, yaitu sebagai berikut: kesatu, Dewan Kemakmuran Masjid Rahmatan Lil'alamin hendaknya lebih mensosialisasikan standar kegiatan kepada seluruh Santri Eco Pesantren. Kedua, Dalam proses pengawasan, koordinasi Dewan Kemakmuran Masjid dan Ikatan remaja Masjid Rahmatan Lil'alamin yang dilakukan hendaknya lebih maksimal, agar dalam pelaksanaannya bisa berjalan dengan baik. Ketiga, Tindakan perbaikan langsung diharapkan bisa lebih tegas 
tidak hanya memberikan saran dan arahan saja, sehingga santri yang melakukan penyimpangan merasa enggan untuk melakukan kesalahan.

\section{DAFTAR PUSTAKA}

Alkhairy, M.S. G. (2017). Peran Pimpinan Pondok Pesantren Dalam Meningkatkan Kualitas Dakwah Santri. Anida (Aktualisasi Nuansa Ilmu Dakwah), Volume17, Nomor 1, 57-74.

Gazalba, S. (1989). Mesjid Pusat Ibadat dan Kebudayaan Islam. Jakarta: Pustaka AlHusna.

Harahap, S. S. (1996). Manajemen Masjid: Suatu Pendekatan Teoritis dan Organisatoris. Yogyakarta: PT. Dana Bhakti Prima Yasa.

Hasibuan, M. S.P. (2003). Manajemen: Dasar, Pengertian, dan Masalah. Jakarta: PT Bumi Aksara.

Hasibuan, M. S.P. (2007). Manajemen: Dasar, Pengertian, dan Masalah. Jakarta: PT Bumi Aksara.

Hasibuan, M. S.P. (2011). Manajemen: Dasar, Pengertian, dan Masalah. Jakarta: PT Bumi Aksara.

Hidayatullaoh, A. Herman \& Setiawan. A. I. Pembinaan Akhlak Narapidanadi Pondok Pesantren At-Taubah Lembaga Pemasyarakatan Cianjur. Tadbir: Jurnal Manajemen Dakwah. Volume 1, Nomor 1, 35-50.

Huda, M.(2018). Manajemen Organisasi Santri Dalam Mewujudkan Pasantren yang Lebih Baik. Tadbir: Jurnal Manajmen Dakwah. Volume 3, Nomor 2, 3562.

Julitriarsa, Djati \& Jhon S. (1992). Manajemen Umum Sebuah Pengantar. Yogyakarta: BPFE.

Madjid, N. (1997). Bilik-bilike pesantren Sebuab Potret Perjalanan. Jakarta: Paramadina. Mustofa, A.K. Muhyiddin, A. \& Nase. (2017). Manajemen Majlis Taklim dalam Meningkatkan Fungsi Masjid. Tadbir: Jurnal Manajemen Dakwah. Volume 2, Nomor 1, 1-17.

Nugraha, F. (2016). Manajemen Masjid: Panduan Pemberdayaan Fungsi-Fungsi Masjid . Bandung: Lekkas.

Poerwodarminto. (1997). Kamus Besar Bahasa Indonesia. Jakarta: Balai Pustaka.

Qadaruddin, M. (2016). Peran Dakwah Masjid dalam Peningkatan Kualitas Hidup Masyarakat. Ilmu Dakwah:Academic Journal For Homiletic Studies. Vol 10, No 2. Sadiah, D. (2015). Metode Penelitian Dakwah Pendekatan Kualitatif dan Kuantitatif. Bandung: PT Remaja Rosdakarya.

Sarwoto. (1981). Dasar-dasar Organisasi dan Manajemen. Jakarta: Balai Aksara.

Yasmadi. (2005). Modernisasi Pesantren: Kritik Nurcholish Madjid Terhadap Pendidikan Islam Tradisional. Jakarta: Ciputat Press.

Yunus. W. N. (2013). Teori Organisasi. Majalengka: Universitas Majalengka. 